\title{
VICTERS -Reaching The Unreached: How Do Secondary School Students Of Kerala Utilise?
}

\author{
Sathiyan. $S^{1}$, V. Sumangala ${ }^{2}$ \\ 1(Research Scholar Department of Education, University of Calicut, Kerala) \\ 2(Professor and Head (Retd.) of the Department of Education, University of Calicut, Kerala)
}

\begin{abstract}
Government of Kerala has been utilising the service of EDUSAT - the educational satellite - and set up the first Interactive Broadband network for school education in India- the 'ViCTERS' (Virtual Classroom Technology on EDUSAT for Rural Schools), which is now re-named as "VICTERS"-Versatile ICT Enabled Resource for Students since 2005. VICTERS telecast the programmes pertaining to school education and the channel operates 17 hours daily from 6 a.m. to 11 p.m. The programmes are chartered to cater the needs of educational community of Kerala schools including students, teachers and educational administrators. The present study is an end user study to know how far standard IX Students of Kerala Secondary Schools utilise such programmes by a survey design administering a structured questionnaire. Statistical analysis used for the study is Percentage analysis for Total sample and Sub samples.
\end{abstract}

Key words: EDUSAT, Survey study, Utilisation, VICTERS

\section{Introduction}

From the very beginning of Television, educationists argued the potential of the medium to teach and to expand knowledge beyond a world of viewers in everyday life. The representation of information using visual and auditory cues as well as language is well suited for young children's learning and comprehension [1]. The Senior Secondary School Students of Delhi enjoyed the strength and weakness of this unique medium in the teaching-learning process through the Secondary School Television project in 1961. Further efforts of Television teaching extended from Satellite Instruction Television Experiment (SITE) in 1975 to EDUSAT in 2004 [2].

Studies conducted by [3], [4] and [5] found that Television motivated self learning and educational interests of the Students. Realising the impact of Television on Students, ISRO has taken effort in connecting the communication satellites with remote areas and for using the Television broadcasting for mass education. Mody [6] reported effectiveness of this ETV programmes in terms of language development, knowledge of political events etc. Educational Technology cell of SCERT of Meghalaya [7] reported in their study on introduction of TV in educational field of Meghalaya that educational telecast would make teaching-learning process easier and interesting.

In the year 2004, the Government of India launched a dedicated satellite called EDUSAT specially configured for audio-visual medium, employing digital interactive classroom and multimedia delivery [8]. The Government of Kerala has been utilizing the service of EDUSAT (The EDUSAT service is now shifted to INSAT - 4CR due to termination of services from EDUSAT) with a scheme named 'VICTERS' (Versatile ICT Enabled Resource for Students) using the broad band facilities offered by EDUSAT.

VICTERS has two modes of operation. The interactive mode, operated through Satellite Interactive Terminal was commissioned on $28^{\text {th }}$ July 2005 . The non interactive mode with Receive Only Terminals, the VICTERS channel was officially inaugurated on $3^{\text {rd }}$ August 2006 ((http:it school.gov.in victers details.php.).

The non-interactive mode of VICTERS otherwise called VICTERS channel the first educational channel of the country telecast programmes sensitive to school curriculum and caters the teachers and students on a need based manner. The channel operates for 17 hours daily from 6 a.m. to 11 p.m. The channel is now available through out the state through Direct To Home (DTH) or Cable services and also available live through internet at www.victers.it school. gov. in. The channel has given the possibility for a student to learn at any where, any time or any pace using a Personal Computer and net connection. Teacher could use the Television inside the classroom to give much desired multi-sensory approach to make classroom teaching a joyful experience. The project envisions a tri-partite intervention with Teachers, Students and VICTERS inside the classroom.

VICTERS started a programme named 'Class time' in the year 2011-12 academic year. The programme provide classes on the topics of Science and Mathematics of standard eighth and as a continuation of the programme, they provide classes for the topics of nineth standard for the academic year 2012- 2013. In addition to this, there are programmes related to Literature, Arts, History, Geography, Sports, Information Communication and General awareness. Sandeep Das [9] conducted a study on 'VICTERS channel' to know 
the relevance of the channel as a source of information, education and social interaction. This study is an inquiry in to the nature and extent of utilization of VICTERS channel programmes by Standard IX Students of Kerala.

\section{Research Questions}

The Research Questions which are the focal points to be answered by the study are following.

1) What is the nature and extent of Student utilization of EDUSAT programmes on the general aspects like Place of viewing, Nature of viewing, Time spent per week for watching and Motivators of watching?

2) How much Viewership is reported by Students for select telecast popular EDUSAT programmes?

3) Do there exist Gender difference, School Locale difference and Type of school Management difference in the Utilisation aspect as reported by Students?

\section{Method}

VICTERS channel airs 17 hour programmes daily. The schedule of programmes is published daily in all leading news papers and in VICTERS official web sites. Students can watch the programmes either at their Homes or at School. Here the emphasis is to know the nature and extent of utilisation of VICTERS programmes and hence the study culminates in to Survey type.

\subsection{Population}

The population of the study is Students of Secondary Schools of Kerala.

\subsubsection{Sample}

Sample for the study consists of 351, Standard IX Students of Kerala and this was drawn from selected schools of Kollam, Ernakulam and Kozhikode districts. A purposive sampling had to be done in selecting the sample as the study was to know the Utilisation of the programme and for this, sample of IX $^{\text {th }}$ standard Students who used to view the educational programmes of VICTERS either at School or at their Home was needed. Representation was given to the strata of the population like Gender, School Locale and Type of School Management, as one of the objectives of the study sample was to compare the Utilisation between these sub groups.

\subsection{Tool}

A structured Questionnaire was prepared and used to collect data pertaining to Utilisation of Standard IX Students. Along with demographic details of Students like Gender, School Locale and Type of School Management, the Questionnaire contained five questions pertaining to varied aspects of utilization.

\subsection{Statistical techniques}

The responses of Students were analysed using Percentage Analysis.

\section{Analysis And Discussion Of Results}

Utilisation of EDUSAT programmes was studied for Place of viewing, Nature of viewing, Time spend per week for watching, Motivators of watching and Viewership of selected aired programmes.

Utilisation aspects of VICTERS channel were studied by administering Questionnaire to Standard IX Students of Secondary Schools. Questionnaire seeks answers on the five aspects of utilisation of VICTERS programme. Details of each aspect studied for the Total sample and for Sub samples based on Gender, School Locale and Type of School Management. Results are shown in Tables and followed by discussion of results.

\subsection{Place of viewing}

Qn.1.Where do you watch VICTERS Programmes?

Responses obtained for Place of viewing of VICTERS programmes for the Total and relevant Sub samples are presented in "Table" 1.

Table 1: Place of viewing of VICTERS programmes for Total and Sub samples of Students

\begin{tabular}{|c|c|c|c|c|c|c|c|}
\hline \multirow{3}{*}{ Place of Viewing } & \multirow{3}{*}{$\begin{array}{c}\text { Total } \\
\text { sample } \\
\mathbf{N}=\mathbf{3 5 1} \\
(\%)\end{array}$} & \multicolumn{6}{|c|}{ Sub samples } \\
\hline & & \multicolumn{2}{|c|}{ Gender } & \multicolumn{2}{|c|}{ School Locale } & \multicolumn{2}{|c|}{ School Management } \\
\hline & & $\begin{array}{c}\text { Girls } \\
\mathrm{N}=207 \\
(\%)\end{array}$ & $\begin{array}{c}\text { Boys } \\
\text { N=144 } \\
(\%)\end{array}$ & $\begin{array}{c}\text { Rural } \\
\mathbf{N}=247 \\
(\%)\end{array}$ & $\begin{array}{c}\text { Urban } \\
\mathrm{N}=104 \\
(\%)\end{array}$ & $\begin{array}{c}\text { Aided } \\
\mathrm{N}=126 \\
(\%)\end{array}$ & $\begin{array}{c}\text { Govt. } \\
\mathbf{N = 2 2 5} \\
(\%)\end{array}$ \\
\hline School & 11.40 & 14.01 & 7.64 & 10.93 & 12.50 & 9.52 & 12.44 \\
\hline Home & 86.61 & 83.57 & 90.97 & 86.23 & 87.50 & 84.92 & 87.56 \\
\hline School and Home & 1.99 & 2.42 & 1.39 & 2.83 & 0.00 & 5.56 & 0.00 \\
\hline
\end{tabular}


The data in "Table" 1 illustrates that $86.61 \%$ of the Total sample of Students view the programmes at Home; $11.40 \%$ at School and only one point nine nine percent both at School and Home. The Sub sample analysis also shows the same pattern of result as that of Total sample. That is majority of the Students (83.5790.97\%) watch EDUSAT programmes at Home.

\subsection{Nature of viewing}

Qn.2. What kind of viewer are you?

Nature of viewing was studied with reference to whether the Students are Daily viewers/ Favourite programme viewers/ Holiday viewers. Responses are tabulated for Total sample and Sub samples in "Table" 2.

Table 2: Nature of viewing of VICTERS programmes for Total and Sub samples of Students

\begin{tabular}{|c|c|c|c|c|c|c|c|}
\hline \multirow[b]{3}{*}{ Nature of Viewing } & \multirow{3}{*}{$\begin{array}{c}\text { Total } \\
\text { sample } \\
\mathbf{N}=\mathbf{3 5 1} \\
(\%)\end{array}$} & \multicolumn{6}{|c|}{ Sub samples } \\
\hline & & \multicolumn{2}{|c|}{ Gender } & \multicolumn{2}{|c|}{ School Locale } & \multicolumn{2}{|c|}{$\begin{array}{c}\text { School } \\
\text { Management }\end{array}$} \\
\hline & & $\begin{array}{c}\text { Girls } \\
\mathbf{N}=207 \\
(\%)\end{array}$ & $\begin{array}{c}\text { Boys } \\
\mathrm{N}=144 \\
(\%)\end{array}$ & $\begin{array}{c}\text { Rural } \\
\mathbf{N}=247 \\
(\%)\end{array}$ & $\begin{array}{c}\text { Urban } \\
\mathrm{N}=104 \\
(\%)\end{array}$ & $\begin{array}{c}\text { Aided } \\
\mathrm{N}=126 \\
(\%)\end{array}$ & $\begin{array}{c}\text { Govt. } \\
\mathbf{N}=225 \\
(\%)\end{array}$ \\
\hline Daily viewer & 11.11 & 11.11 & 11.11 & 10.53 & 12.50 & 13.49 & 9.78 \\
\hline Favourite programme viewer & 49.57 & 50.72 & 47.92 & 48.18 & 52.88 & 52.38 & 48.00 \\
\hline Holiday viewer & 39.32 & 38.16 & 40.97 & 41.30 & 34.62 & 34.13 & 42.22 \\
\hline
\end{tabular}

With regard to the nature of viewing, data suggest that majority of students are Favourite programme Viewers (49.57\%) and Holiday Viewers (39.32\%). A similar pattern is reflected in the data of all Sub samples. 4.3. Time spent in a week for watching the VICTERS programmes

Qn. 3. How much time do you spent in a week for watching the VICTERS programmes?

Time spent per week by Students for watching the EDUSAT programmes was elicited by giving three options like Below two hours, Two to four hours and Above four hours. The consolidated data on these are given in "Table" 3.

Table 3: Time spent per week for viewing VICTERS programmes of Total and Sub samples

\begin{tabular}{|c|c|c|c|c|c|c|c|}
\hline \multirow{3}{*}{ Time spent per week } & \multirow{3}{*}{$\begin{array}{c}\text { Total } \\
\text { sample } \\
\mathbf{N}=351 \\
(\%)\end{array}$} & \multicolumn{6}{|c|}{ Sub samples } \\
\hline & & \multicolumn{2}{|c|}{ Gender } & \multicolumn{2}{|c|}{ School Locale } & \multicolumn{2}{|c|}{$\begin{array}{c}\text { School } \\
\text { Management }\end{array}$} \\
\hline & & $\begin{array}{c}\text { Girls } \\
\mathbf{N}=207 \\
(\%)\end{array}$ & $\begin{array}{c}\text { Boys } \\
\mathrm{N}=144 \\
(\%)\end{array}$ & $\begin{array}{c}\text { Rural } \\
\mathrm{N}=247 \\
(\%)\end{array}$ & $\begin{array}{c}\text { Urban } \\
\mathrm{N}=104 \\
(\%)\end{array}$ & $\begin{array}{c}\text { Aided } \\
\mathrm{N}=126 \\
(\%)\end{array}$ & $\begin{array}{c}\text { Govt. } \\
\text { N=225 } \\
(\%)\end{array}$ \\
\hline Below two hours & 49.57 & 55.56 & 40.97 & 54.25 & 38.46 & 51.59 & 48.44 \\
\hline $2-4$ hours & 40.74 & 38.16 & 44.44 & 36.03 & 51.92 & 37.30 & 42.67 \\
\hline Above four hours & 9.69 & 6.28 & 14.58 & 9.72 & 9.62 & 11.11 & 8.89 \\
\hline
\end{tabular}

The consolidated data reveals that $38.46-55.56 \%$ of the Total and Sub samples of Students watch the VICTERS programmes for less than 2 hours only in a week. The percent of viewing for 2-4 hours per week ranges between $36.03-51.92 \%$. The range of percentage of viewership for more than four hours per week is only 6.28-14.58\%.

Despite the delivery of VICTERS programmes for 119 hours a week, almost half of the students (49.57\%) utilizes only less than two hours per week and 40.74 percent of the Students utilise between two to four hours per week.

\subsection{Motivators of watching the VICTERS programmes}

Qn. 4. Who among the following motivates you to watch VICTERS programmes?

Students were given options to mark one or more responses like Teachers, Parents, Friends and None as motivators for them to watch VICTERS programmes. Responses are tabulated and presented in "Table" 4.

Table 4: Motivators of viewing of VICTERS programmes for Total and Sub samples

\begin{tabular}{|c|c|c|c|c|c|c|c|}
\hline \multirow[b]{3}{*}{ Motivators of viewing } & \multirow{3}{*}{$\begin{array}{c}\text { Total } \\
\text { sample } \\
\mathbf{N}=351 \\
(\%)\end{array}$} & \multicolumn{6}{|c|}{ Sub samples } \\
\hline & & \multicolumn{2}{|c|}{ Gender } & \multicolumn{2}{|c|}{ School Locale } & \multicolumn{2}{|c|}{ School Management } \\
\hline & & $\begin{array}{c}\text { Girls } \\
\mathbf{N}=207 \\
(\%)\end{array}$ & $\begin{array}{c}\text { Boys } \\
\mathrm{N}=144 \\
(\%)\end{array}$ & $\begin{array}{c}\text { Rural } \\
\mathbf{N}=247 \\
(\%)\end{array}$ & $\begin{array}{c}\text { Urban } \\
\mathrm{N}=104 \\
(\%)\end{array}$ & $\begin{array}{c}\text { Aided } \\
\mathbf{N}=126 \\
(\%)\end{array}$ & $\begin{array}{c}\text { Govt. } \\
\text { N=225 } \\
(\%)\end{array}$ \\
\hline Teachers & 19.66 & 16.91 & 23.61 & 21.05 & 16.35 & 15.08 & 22.22 \\
\hline Parents & 16.24 & 16.91 & 15.28 & 17.81 & 12.50 & 19.05 & 14.67 \\
\hline Friends & 8.26 & 6.76 & 10.42 & 9.31 & 5.77 & 7.94 & 8.44 \\
\hline Nobody & 0.85 & 1.45 & 0.00 & 0.40 & 1.92 & 1.59 & 0.44 \\
\hline Teachers and parents & 30.48 & 33.33 & 26.39 & 28.74 & 34.62 & 26.98 & 32.44 \\
\hline Teachers and friends & 7.12 & 4.35 & 11.11 & 6.07 & 9.62 & 7.94 & 6.67 \\
\hline Parents and friends & 2.85 & 2.90 & 2.78 & 2.43 & 3.85 & 3.97 & 2.22 \\
\hline Teachers, parents and friends & 14.53 & 17.39 & 10.42 & 14.17 & 15.38 & 17.46 & 12.89 \\
\hline
\end{tabular}


This question sought answers from the viewers about who are the motivators for watching the programmes. For the Total sample, teachers, parents and friends were reported as the motivators by $19.66 \%$, $16.24 \%$ and $8.26 \%$ respectively. Only $0.85 \%$ of Students reported watching the programme on their own interest. Combinations of teachers and parents, teachers and friends, parents and friends and teachers, parents and friends registered $30.48 \%, 7.12 \%, 2.85 \%$ and $14.53 \%$ respectively suggesting that Students are watching not because of their own interest but by teachers, parents and friends. Similar pattern of motivation is shown for all the Subsample of Students. Self motivated viewers $(0.85 \%)$ of EDUSAT prograame are very meager and Students view because of the motivation either from teachers or parents and friends.

\subsection{Programme wise utilisation}

Qn.5. Given are some of the telecast programmes, indicate the programmes you viewed by putting tick mark against each.

The respondents are given 10 telecast VICTERS programmes and asked to indicate programmes they viewed and it is presented in "Table" 5 for the Total sample and Sub samples.

Table 5: Viewership of the 10 telecast VICTERS programmes for the Total sample and Sub samples

\begin{tabular}{|c|c|c|c|c|c|c|c|}
\hline \multirow[b]{3}{*}{ Programmes } & \multirow{3}{*}{$\begin{array}{l}\begin{array}{c}\text { Total } \\
\text { sample }\end{array} \\
\mathbf{N}=351 \\
(\%)\end{array}$} & \multicolumn{6}{|c|}{ Sub samples } \\
\hline & & \multicolumn{2}{|c|}{ Gender } & \multicolumn{2}{|c|}{ School Locale } & \multicolumn{2}{|c|}{$\begin{array}{c}\text { School } \\
\text { Management }\end{array}$} \\
\hline & & $\begin{array}{c}\text { Girls } \\
\text { N=207 } \\
(\%) \\
\end{array}$ & $\begin{array}{c}\text { Boys } \\
\mathrm{N}=144 \\
(\%) \\
\end{array}$ & $\begin{array}{c}\text { Rural } \\
\text { N=247 } \\
(\%)\end{array}$ & $\begin{array}{c}\text { Urban } \\
\mathrm{N}=104 \\
(\%)\end{array}$ & $\begin{array}{c}\text { Aided } \\
\mathrm{N}=126 \\
(\%)\end{array}$ & $\begin{array}{c}\text { Govt. } \\
\text { N=225 } \\
(\%)\end{array}$ \\
\hline Sports education & 31.05 & 30.92 & 31.25 & 29.55 & 34.62 & 33.33 & 29.78 \\
\hline Ormayile Malayalam & 36.75 & 34.30 & 40.28 & 36.44 & 37.50 & 38.89 & 35.56 \\
\hline Distinguished personalities & 34.76 & 30.92 & 40.28 & 31.58 & 42.31 & 35.71 & 34.22 \\
\hline Bhasha parichayam & 44.73 & 46.38 & 42.36 & 45.75 & 42.31 & 48.41 & 42.67 \\
\hline Communicative English & 41.88 & 41.55 & 42.36 & 40.89 & 44.23 & 42.86 & 41.33 \\
\hline Class time & 28.49 & 25.12 & 33.33 & 27.13 & 31.73 & 34.13 & 25.33 \\
\hline Innalekalile innu & 41.88 & 40.58 & 43.75 & 40.89 & 44.23 & 42.86 & 41.33 \\
\hline Learn a word a day & 28.49 & 27.54 & 29.86 & 25.91 & 34.62 & 30.16 & 27.56 \\
\hline Great teachers & 32.19 & 32.85 & 31.25 & 30.77 & 35.58 & 39.68 & 28.00 \\
\hline Protected monuments & 37.89 & 36.23 & 40.28 & 36.03 & 42.31 & 38.10 & 37.78 \\
\hline
\end{tabular}

Out of the given ten programmes, only three have viewership of $40 \%$ and above in the Total sample of Students. These three programmes in the order of viewership are Bhasha parichayam (44.73\%), Communicative English (41.88\%), and Innalekalile innu (41.88\%). And all others have viewership in the range of 31 to 38 percent except Class time $(28.49 \%)$ and learn a word $(28.94 \%)$.

The Sub sample data also reveals the same trend of the Total sample in respect of viewership. The result indicates that the viewership of the EDUSAT programme among the Secondary School Students is low. The three programmes Bhasha parichayam (44.73\%), Communicative English (41.88\%) and Innalekalile innu $(41.88 \%)$ are having relatively higher viewership though it is below 50 percent.

\section{Findings Of The Study}

1. Of the Total sample, 86.61 percent of Students view VICTERS programmes at Home. Similarly, among the Sub samples like Gender, School Locale and Type of School Management, majority (83.57-90.97\%) of Students watch VICTERS programmes at Home.

2. With regard to the nature of viewing, the majority of Students are Favourite programme viewers $(49.57 \%)$ and Holiday viewers $(39.32 \%)$.

3. Despite the delivery of VICTERS programmes for 119 hours a week, almost half of the Students (49.57\%) utilise only less than two hours per week and 40.74 percent of the Students utilise between two to four hours per week.

4. Self motivated viewers $(0.85 \%)$ of EDUSAT programme are very meager and Students view because of the motivation either from teachers or parents and friends.

5. The study indicates that the viewership of the VICTERS programmes among the Secondary School Students is low. The three programmes Bhasha parichayam (44.73\%), Communicative English (41.88\%), and Innalekalile innu (41.88\%) are having relatively higher viewership though it is below 50 percent.

\section{Conclusion}

The effect of Television viewing on children may have direct or indirect effects. Direct effect may operate via learning specific cognitive or academic skills. Indirect effect may operate through motivational process. Even though schools are provided with EDUSAT facilities, the viewing at school is very low, most of the Students view the programmes at Home. The viewership analysis and time spent for viewing indicates the VICTERS programmes are underutilized. The Students are not self motivated to view the programmes. The 
study reveals the urgent need of involvement of educational authorities to improve the functioning of a far sighted Government programme. VICTERS authorities may take steps to improve the Utilisation of programmes and Educational authorities have to motivate Teachers and Students for better utilisation.

\section{References}

[1]. S.M.Fisch, and R.T. Truglio (Ed.). "G" is for "growing": thirty years of research on children and Seasame Street. (Mahwah, NJ: Lawrence Erlbaum Associates, 2001a).

[2]. W.J. Starosta, and A.H. Merriam, The Impact of Media Technology in Peasant Societies: The Case of SITE. Educational Communication and Technology, 34(1), 1986, 39-45.

[3]. P.C. Mohanty, A critical study of the educational television programmes for primary school children in the state of Orissa. doctoral diss., Utkal University,Utkal, 1988.

[4]. I. Arularam, Evaluation of the UGC country-wide educational television, M.Phil diss., Madurai Kamaraj University, Madurai, 1990.

[5]. A.M. Kapadia, The impact of television on students learning, doctoral diss., Utkal University, Utkal, 1992

[6]. B. Mody, Lessons from the Indian Satellite Experiment.Educational Broadcasting Experiments. Educational Broadcasting international. 36 (1) 1976.

[7]. Educational Technology Cell, Need assessment studies : Introduction of TV in educational work in Meghalaya. Independent study, State Council of Educational Research and Training, Shillong, 1988.

[8]. A. Behera, EDUSAT and its Utilization (NCERT, New Delhi, 2006).

[9]. A.S. Sandeep Das, The Reach and Effectiveness of Educational Channels: A Case [study of the ViCTERS Educational Channel. Unpublished diss., University of Calicut, Kerala, 2009. 